\title{
Manifesto to the Mexican Republic
}





\section{Manifesto to \\ the Mexican Republic}

which Brigadier General José Figueroa,

Commandant and

Political Chief of Upper California,

presents on his conduct and on that of

José María de Hijar and José María Padrés

as Directors of Colonization in 1834 and 1835

TRANSLATED, WITH AN INTRODUCTION AND NOTES BY

C. Alan Hutchinson

University of California Press

Berkeley Los Angeles London 
University of California Press

Berkeley and Los Angeles, California

University of California Press, Ltd.

London, England

Copyright (C) 1978 by

The Regents of the University of California

ISBN 0-520-03347-7

Library of Congress Catalog Card Number: 76-47992

Printed in the United States of America

123456789 
For Jean, Robert, and Mary 
